\title{
Antisemitism and Anti-Zionism in Iran: The Effects of Identity, Threat and Political Trust
}

\author{
Rusi Jaspal \\ De Montfort University, Leicester, UK
}

\begin{abstract}
Antisemitism and anti-Zionism constitute two important ideological building blocks of the Islamic Republic of Iran. This article is the first to present quantitative empirical survey data elucidating attitudes towards Jews and Israel among an opportunity sample of Iranians. This article examines the correlates of antisemitism and anti-Zionism in Iran with particular attention to the effects of identity, threat and political trust. Consistent with emerging research into antisemitism and anti-Zionism, there was a positive association between both forms of prejudice, suggesting social psychological overlap between the constructs. Given the pervasiveness of antisemitic and anti-Zionist representations in Iran, there were no significant differences in levels of anti-Zionism or antisemitism on the basis of gender and educational orientations. Political conservatives did manifest greater antisemitism and anti-Zionism than political reformists, although both groups scored highly on these scales. There was a significant interaction effect of Iranian national identity and political trust on antiZionism, and a significant interaction effect of Muslim religious identity and political trust on antisemitism. Political trust was by far the most powerful predictor of both forms of prejudice, followed by the perception of identity threat. These observations are considered through the lenses of Social Identity Theory and Identity Process Theory from social psychology.
\end{abstract}

\section{Keywords}

antisemitism; anti-Zionism; Iran; Israel; Jews; social identity; identity process theory; social psychology

\section{Correspondence}

Dr Rusi Jaspal, Self and Identity Research Group, Faculty of Health and Life Sciences, De Montfort University, Leicester LE109BH, United Kingdom. E-mail: rusi.jaspal@cantab.net

\section{Citing this article}

Jaspal, R. (2015). Antisemitism and Anti-Zionism in Iran: The Effects of Identity, Threat and Political Trust. Contemporary Jewry, 35(3), 211-235

\section{ACKNOWLEDGEMENTS}

The author would like to thank Dr Marco Cinnirella, Professor Harriet Hartman, Professor Samuel Heilman, and four anonymous reviewers, all of whom provided constructive feedback on previous versions of this manuscript. He would also like to acknowledge the input of the Iranian research assistant who, understandably, wishes to remain anonymous. 


\title{
Antisemitism and Anti-Zionism in Iran: The Effects of Identity, Threat and Political Trust
}

\author{
Rusi Jaspal \\ De Montfort University, Leicester, UK
}

\begin{abstract}
Antisemitism and anti-Zionism constitute two important ideological building blocks of the Islamic Republic of Iran. This article is the first to present quantitative empirical survey data elucidating attitudes towards Jews and Israel among an opportunity sample of Iranians. This article examines the correlates of antisemitism and anti-Zionism in Iran with particular attention to the effects of identity, threat and political trust. Consistent with emerging research into antisemitism and anti-Zionism, there was a positive association between both forms of prejudice, suggesting social psychological overlap between the constructs. Given the pervasiveness of antisemitic and anti-Zionist representations in Iran, there were no significant differences in levels of anti-Zionism or antisemitism on the basis of gender and educational orientations. Political conservatives did manifest greater antisemitism and anti-Zionism than political reformists, although both groups scored highly on these scales. There was a significant interaction effect of Iranian national identity and political trust on antiZionism, and a significant interaction effect of Muslim religious identity and political trust on antisemitism. Political trust was by far the most powerful predictor of both forms of prejudice, followed by the perception of identity threat. These observations are considered through the lenses of Social Identity Theory and Identity Process Theory from social psychology.
\end{abstract}

\section{INTRODUCTION}

Antisemitism and anti-Zionism are often purported to constitute separate and delineable constructs. Antisemitism has been defined as "a persisting latent structure of hostile beliefs towards Jews" (Fein, 1987, p. 67), while anti-Zionism is conceptualized as the denigration and delegitimization of the State of Israel (for whatever reason) (Jaspal, 2014). Iran makes no secret of its fiercely anti-Zionist position, which became an official state policy following the Islamic Revolution in 1979, but its leaders categorically deny that their regime is in any way antisemitic. In short, Iran officially makes a distinction between antisemitism and anti-Zionism, arguing that opposition to the existence of Israel does not amount to antisemitism (Shahvar, 2009), but it is difficult to know if this distinction is upheld in the Iranian general population. Iran vocally supports Palestinian sovereignty over the whole of present-day Israel, the West Bank and Gaza, and actively calls for the destruction of the Jewish State. This, many argue, reflects the anti-Zionist stance of the Iranian government, rather than antisemitism. Yet, Iranian leaders, including former president Ahmadinejad and the current Supreme Leader Khamenei, have made overtly antisemitic remarks, often blurring the boundaries between Jews and the State of Israel in their anti-Zionist diatribes (Shahvar, 2009). Moreover, former president Ahmadinejad's blatant and repeated denial of the Holocaust exemplified the regime's disdain not only for Israel but for the Jewish people as a whole (Jahanbegloo, 2007). 
Thus, despite the Iranian regime's keen delineation of the two forms of prejudice, it is likely that they are as inter-related in the minds of people as they are in the rhetoric of Iranian leaders.

There is now a body of social sciences research into the development and deployment of anti-Zionism and antisemitism in Iran (Jaspal, 2013a; Litvak, 2006; Shahvar, 2009). Much research in this area tends to focus upon the political functions of this ideological stance (Küntzel, 2010; Takeyh, 2006) and its manifestation in social and political institutions in Iran, such as the newspaper media (Jaspal, 2014; Klein, 2009). There is only very limited empirical insight into attitudes towards Jews and Israel among the Iranian general population (though see Jaspal, 2014, for smallscale qualitative interview research). This article is the first to present quantitative empirical survey data elucidating attitudes towards Jews and Israel among an opportunity sample of Iranians. This article examines the correlates of antisemitism and anti-Zionism in Iran with particular attention to the effects of identity, threat and political trust.

\section{Antisemitism and anti-Zionism in Iran}

Zionism can be described as an ethnonationalist ideology, whereby Israel is regarded as "the expression of the Jewish people's right to national self-determination" (Beller, 2007, p. 226). However, the Iranian government views Zionism as a racist, oppressive Nazi ideology (Takeyh, 2006). Since Iran withdrew its recognition of the State of Israel, it has systematically referred to the Jewish State by demeaning terms, such as the "Zionist regime" and "Occupied Palestine," which are intended to deprive Israel of state-like characteristics and thereby delegitimize it (Jaspal, 2013b). In addition to its active dissemination of delegitimizing social representations, Iran is a major funder of organizations committed to the destruction of Israel (Palmer-Harik, 2004).

Antisemitism has been repeatedly manifested at the institutional level in Iran, but it is also observable on a social level. As an Islamic Republic, Iran's stance on Jews and Israel is deeply entwined with theological representations - Kressel's (2012) groundbreaking book on Muslim antisemitism highlights some of the ways in which Islamic theological representations may be mobilized by Muslim antisemites in order to demonize Jews and Israel, and to instill in subsequent generations the necessity of targeting these outgroups. Moreover, Shahvar (2009) highlights the long-standing antisemitism of Shiite Islam (which is the dominant denomination of Islam in Iran) and the ways in which this has persisted in present-day Iran, particularly after the 1979 Revolution. For instance, during the Qajar dynasty in Iran, Iranian Jews faced blood libel accusations, persecution, forced conversions - the forced conversion of Mashadi Jews to Islam in 1839 being an infamous case - and even pogroms (Levy, 1999; Tsadik, 2005, 2010). Anti-Zionism and, arguably, antisemitism have become important ideological components of Iranian policy since 1979, which marked the fall of the Pahlavi dynasty in Iran - a "golden age" for Iranian Jewry (Sanasarian, 2000).

Post-revolutionary Iran does not have a strong tradition of political parties. Following the 1979 Islamic Revolution, the Islamic Republic Party ruled Iran until it was dissolved in 1987. There are now several political factions in Iran, such as the Moderation and Development Party, the Islamic Society of Engineers and the Front of Islamic Revolution Stability. Given that the social and political traction of these entities is limited (Asayesh et al., 2010), it is more appropriate to refer to them in terms of more ephemeral "factions", rather than political parties. Iranian national politics is better understood as a dichotomy between "Conservatives" (Persian: 
"osoolgaraa") and "Reformists" (Persian: "eslahtalab"), which has greater resonance among Iranians. For instance, former president Mahmoud Ahmadinejad was formally a member of the Islamic Society of Engineers but he was popularly regarded as a conservative $^{1}$ leader. Similarly, former president Mohammad Khatami, though a member of the Association of Combatant Clerics, was widely perceived as a political reformist. Indeed, the so-called Green Movement, ${ }^{2}$ which emerged in contestation of the re-election of Ahmadinejad in 2009, was a coalition of reformist and liberal political factions, in opposition to the conservatives. This served to further crystallize the conservative vs. reformist dichotomy, albeit with a broad conception of both political identities.

In his overview of anti-Zionism in Iranian politics, Jaspal (2013a) has highlighted that the political reformists in Iran have generally sought a more pragmatic stance on relations with both the US and, in a much subtler manner, the State of Israel. However, following the election of conservative president Ahmadinejad, anti-Zionism (and, arguably, also antisemitism) was actively revived in Iranian domestic and foreign politics. Although anti-Zionism is now a particularly important tenet of the conservative political identity in Iran, it is unclear whether there are differences in attitudes towards Israel and Jews among conservative and reformist members of the Iranian general population.

\section{Empirical approaches to antisemitism and anti-Zionism}

As Kressel (2012) notes, there has been relatively little empirical social science research into antisemitism and anti-Zionism in the Islamic world. Much research has focused upon antisemitism in Europe and in Christianity. Previous work has been guided by approaches such as the authoritarian personality (Adorno, FrenkelBrunswik, Levinson, \& Sanford, 1950), obedience to authority (Milgram, 1963), scapegoating (Gregory, 2001), and, more recently, terror management theory (Cohen et al., 2009). No previous studies have examined the roles of identity and political trust in antisemitism and anti-Zionism.

There have been several correlational survey-based studies, which seek to identify the individual traits that appear to be associated with antisemitism. Frindte, Wettig and Wammetsberger (2005) conducted two studies in Germany that examined antisemitism within the context of authoritarianism and social dominance. They showed that individuals who manifested extreme antisemitic attitudes differed significantly from those who scored low on antisemitism with regard to the extent of authoritarianism, readiness for violence, endorsement of National Socialism and political orientation. Moreover, they found that authoritarianism was an important predictor of antisemitism. In a unique cross-cultural examination of the social psychological predictors of antisemitism, Dunbar and Simonova (2003) found that the

\footnotetext{
${ }^{1}$ Ahmadinejad described himself as "osoolgaraa", which literally means "principalist" or "fundamentalist", although in Persian it does not have the same negative connotations that "fundamentalist" has in English. The term "osoolgaraa" can plausibly be defined as "conservative" in that it denotes a conservation of the original, fundamental principles of the Islamic Republic of Iran, as outlined in Ayatollah Khomeini's (1979) Velayat-e Faqih (English Guardianship of Islamic Jurists).

${ }^{2}$ The Green Movement is a largely amorphous superordinate political movement, consisting of various reformist and liberal factions with essentially different specific political goals (Dabashi, 2011). Reformists in the Green Movement like Mohammad Khatami (the former president) and Mir Hossein Mousavi (one of the 2009 presidential candidates) express allegiance to the principle of clerical guardianship as defined in Khomeini's conception of the Islamic Republic, while many of the participants in the Green protests sought greater reform of the political system in Iran through the dismantlement of Islamic theocracy.
} 
relationship between the right-wing extremism personality and antisemitism was positive and that the degree of antisemitic attitudes was similar in both the US and Czech samples, despite the distinct history of intergroup relations between these groups and Jews. These studies highlight the importance of personality traits vis-à-vis social and environmental factors.

Several studies have also evidenced the link between particular demographic characteristics and antisemitism. It has been found that male respondents generally manifest greater antisemitism than female respondents (D'Alessio \& Stolzenberg, 1991), that unskilled workers are more antisemitic than professionals (Selznick \& Steinberg, 1969), that education is negatively correlated with antisemitism (Quinley \& Glock, 1979), that younger people are generally less antisemitic than older people (Raab, 1983), and that the higher the concentration of Jews in one's environment, the higher one's level of antisemitism will be (Smith, 1991). While these studies provide important snapshots of antisemitism in particular temporal, cultural and geographical contexts (admittedly, largely in the US), they do not further our understanding of how antisemitism and anti-Zionism function in the Iranian general population or how they are related to one another.

Furthermore, Weil (1985) examined the effects of education on liberalising attitudes in order to decipher the outcomes for antisemitism. In his cross-cultural research, he found that, while education was positively correlated with liberal attitudes towards Jews in the US and the West, the effect of education on liberal attitudes appeared to be weaker or even reversed in non-liberal democracies or countries with a history of authoritarian government. However, in the context of Iran, where anti-Zionism is a state policy and antisemitism is at least passively endorsed by governmental institutions, it is likely that personality traits and key demographic variables, such as level of education, will provide only partial explanations for the endorsement and manifestation of these forms of prejudice. Antisemitic and antiZionist representations appear to be more coercive than in some of the contexts that have hitherto been studied and, thus, it is likely that these forms of prejudice will cut across such demographic divisions.

Several scholars argue that anti-Zionism amounts to antisemitism (Chesler, 2003; Fischel, 2005). This argument generally focuses upon the notion that antisemitism is causally related to anti-Zionism. A number of empirical studies have distinguished between antisemitism and anti-Zionism variables, which are operationalized differently. In a survey study, Kaplan and Small (2006) found that that the prevalence of antisemitic views significantly increased with participants' degree of anti-Zionist sentiment, even after controlling for other factors. Similarly, in their experimental research into mortality salience and attitudes towards Jews and Israel, Cohen et al. (2009) reasoned that, because modern sensibilities discourage people from manifesting overt prejudice such as classic antisemitism, individuals would be more likely to channel their prejudice via a more socially acceptable route, namely anti-Zionism. They argued that there is likely to be a bi-directional causality between antisemitism and anti-Zionism - antisemites are more likely to express antiZionism, while anti-Zionism can also accentuate antisemitism. Frindte et al. (2005) argue that "criticism of Israel and anti-Zionism could represent special forms of substituted communication of anti-Semitic attitudes and, thus, could be described as modern forms or derivations of anti-Semitism" (p. 245). In a survey study antisemitism among Arab and non-Arab Muslims, Baum and Nakazawa (2007) found that antisemitism and anti-Zionism were moderately correlated and that the main effect of religion on anti-Zionism was significant. 
Consistent with these studies that have focused largely upon Western, industrialized societies, the present study of attitudes among Iranians treats antisemitism and anti-Zionism as two distinct variables and examines the relationship between them. Although the two forms of prejudice are in fact highly inter-related in the rhetoric and positions of the Iranian political leadership, it is unclear how they are related in the minds of Iranians.

\section{Social identity and political trust}

In addition to personality traits, social identities are important predictors of prejudice (Brown, 2000; Tajfel, 1982). In developing Social Identity Theory, Tajfel (1982) argued that in most human interactions individuals' group memberships are salient and can override their personal, individualizing traits. According to the theory, human beings are motivated psychologically to identify with social groups because they provide feelings of belonging, self-esteem and distinctiveness. Crucially, by viewing oneself primarily in terms of one's membership in relevant social groups, one begins to think and act primarily as a member of that group (Turner et al., 1987). The stereotypes, myths, beliefs and social representations associated with, and generally accepted by, that group will become active and salient in the group member's meaning-making.

Religion is a social identity that has been associated with antisemitism. For instance, in their study of Christian antisemitism in the Netherlands, Konig et al. (2000) highlighted that Christian religion was a determinant of both religious and secular forms of antisemitism, which in turn exhibited the importance of religious imagery in contemporary secular thinking vis-à-vis Jews. It has been observed that in Iran Islamic theology is often invoked to construct Jews as inferior and "impure" and to justify antisemitism and anti-Zionism (Shahvar, 2009). In a unique and insightful survey study of antisemitism among both Christians and Muslims in North America, Baum (2009) found that, while personal identity was the strongest predictor of antisemitism among Christians (i.e. the perception that one has personally been mistreated by Jews), social identity was the strongest predictor among Muslim respondents (i.e. the perception that one's Muslim ingroup was threatened by Jews). Consistent with the notion of social identity as a predictor of prejudice but in the context of national identity, Jaspal (2014) found that anti-Zionism was viewed as central to Iranian national identity and that young Iranians accentuated their antiZionist stance as a means of asserting this identity. In short, individuals may come to believe that antisemitism and anti-Zionism are essential tenets of their social identities and that any acceptance of Jews or Israel would be inconsistent with their group membership. Given that social identities are socially constructed (Tajfel, 1982), this is likely to be dependent on the sorts of messages and representations disseminated at social and institutional levels which are subsequently internalized by individuals.

Anti-Zionism is a central tenet of the political ideology of the Islamic Republic of Iran and many people do derive their knowledge of Israel and Jews from political representations (Litvak, 2006). Thus, it is likely that political trust is an important factor in individuals' perceptions of Jews and Israel. As Miller and Listhaug (1990, p. 358) highlights,

[t]rust [..] reflects evaluations of whether or not political authorities and institutions are performing in accordance with normative expectations held by the public. Citizen expectations of how government should operate include, among other criteria, that it be fair, equitable, honest, efficient, and responsive to society's needs. In brief, an expression of trust in government (or synonymously political confidence and support) is a summary judgment that the 
system is responsive and will do what is right even in the absence of constant citizens' scrutiny.

History is replete with examples of widespread antisemitism (and, more recently, antiZionism) having ensued from people's trust in their political institutions. Many citizens of Nazi Germany came to view the Jews as a genuine threat to the continuity of the German nation because they trusted the Nazi government that disseminated threat representations (Herf, 2006). The deadly pogroms in Russia ensued from widespread belief in the anti-Jewish propaganda generated by the tsarist government in Russia (Klier \& Lambroza, 1992). Iranians are habitually and systematically taught by governmental institutions (such as the education system) that Israel is the "Little Satan" which must be destroyed and, accordingly, "Death to Israel" is frequently heard in political gatherings in Iran (Kressel, 2009; Shahvar, 2009). It is likely that those citizens of Iran who trust their government, which is known to disseminate deeply anti-Zionist propaganda, punctuated by blatant antisemitism, will be less critical of antisemitic and anti-Zionist representations and, thus, more readily accept and assimilate them to their own thinking.

In theorizing the likelihood of assimilating antisemitic and anti-Zionist representations, it is useful to draw upon Identity Process Theory (Breakwell, 1986; Jaspal \& Breakwell, 2014). According to the theory, identity threat occurs when the individual believes that their sense of continuity, self-esteem, self-efficacy and distinctiveness are somehow jeopardized. Identity threat places the individual in a vulnerable position, forcing them to deploy "coping strategies" to deflect the threat. It has been argued that forms of prejudice, such as Islamophobia and antisemitism, may be associated with attempts to protect the self from identity threat (Jaspal, 2013a; Jaspal \& Cinnirella, 2010). This is most likely to be applicable to groups that are positioned as the ingroup's "Significant Others," that is, outgroups that "threaten (or are perceived to threaten) its presumed ethnic or cultural purity and/or its independence" (Triandafyllidou, 2002, p. 33). Thus, individuals who are placed in a threatening position (for instance, as a result of the government's attempts to construct their relevant identities as being jeopardized by an outgroup) may be more susceptible to expressing antisemitism and anti-Zionism.

\section{Hypotheses}

A series of hypotheses can be extrapolated on the basis of this brief review of relevant theory and research in this area.

$\mathrm{H}_{1}$ : Consistent with emerging research into antisemitism and anti-Zionism (Baum and Nakazawa, 2006; Kaplan \& Small, 2005), there will be a positive association between these forms of prejudice.

$\mathrm{H}_{2}$ : In view of the coerciveness and "stickiness" of negative social representations of Israel and Jews in Iran, there will be no significant differences in levels of antisemitism or anti-Zionism on the basis of gender and educational orientations. However, political conservatives are expected to manifest greater antisemitism and anti-Zionism than reformists.

$\mathrm{H}_{3}$ : Because the Iranian government emphasizes its disdain for Israel, which it constructs as its "Significant Other", both conservatives and reformists should manifest greater anti-Zionism than antisemitism. However, the perception of Jews as 
"the enemy within" should render them more threatening than the State of Israel for Iranians of both political orientations.

$\mathrm{H}_{4}$ : Given the constructed centrality of anti-Zionism to Iranian national identity and its association with the political regime (Jaspal, 2013a), there will be a significant interaction effect of Iranian national identity and political trust on anti-Zionism. Similarly, because antisemitism is socially represented as central to an "authentic" Islamic identity (Baum \& Nakazawa, 2006) and because of Islam's centrality to the political regime, there will be a significant interaction effect of Muslim religious identity and political trust on antisemitism.

$\mathrm{H}_{5}$ : Recent research in the domain of Identity Process Theory suggests that outgroup discrimination may constitute a response to threatened identity (Cinnirella, 2014; Jaspal \& Cinnirella, 2010). Accordingly, it is hypothesized that the perception of identity threat will be positively associated with both anti-Zionism and antisemitism, respectively.

\section{METHOD}

\section{Participants}

This study is based on an opportunity sample of 130 participants. 163 individuals were originally recruited for the study but 33 participants were removed due to missing data on key measures such as antisemitism and anti-Zionism. In a challenging social and political context such as the Iranian one, research into highly sensitive and politicized topics such as antisemitism and anti-Zionism is difficult. It may be impossible to gain access to a representative sample, given that the researcher runs the risk of rousing suspicion about their (political) aims in conducting such research. Foreigners conducting research in Iran have been accused of espionage in the past. ${ }^{3}$ Convenience sampling, though not ideal, was deemed to be the most appropriate method of recruitment in view of the sensitivities surrounding the research. However, attempts were made to limit the resulting sampling bias by recruiting participants in three distinct areas of Tehran (with differing socio-economic statuses) and in online settings.

An Iranian research assistant assisted with data collection in Iran. Although a total of 107 were approached, 68 individuals (44\% of the overall sample) were successfully recruited at three cafeterias in Elahieh (an affluent area in the North of Tehran), Ekbatan (a lower middle class area in the West of Tehran), and Javadiyeh (an economically deprived area in the South of Tehran). 39 individuals refused to complete the survey without reading the information sheet. Permission was obtained from the cafeteria staff to distribute questionnaires, but only the debrief sheet fully disclosed the true aims of the study. All of the respondents who read the information sheet did complete the survey, which may suggest a general willingness among Iranians to express social and political views despite the political pressure for them to conceal views that are inconsistent with the Iranian regime. None of the respondents withdrew their data after reading the debrief sheet. After a while, it was deemed unsafe for the researcher to continue collecting data in these settings due to potential repercussions from the Iranian authorities. For instance, in one of the three cafeterias

\footnotetext{
${ }^{3}$ Reuters, http://uk.reuters.com/article/2014/10/07/uk-iran-rouhani-idUKKCN0HW1PE20141007
} 
the researcher was asked on three occasions if the research was funded by "Zionists", which suggested some suspicion surrounding research into attitudes towards Jews and Israel. In addition, 95 individuals (56\% of the overall sample) completed the questionnaire online. An online version of the questionnaire was created and the link was posted on various social networking websites (e.g. Iranian.com; and Iranian political and cultural pages on Facebook and Twitter) frequented by Iranian Internet users.

The aim was to recruit a fairly heterogeneous sample of Iranians. Most of the participants were men $(\mathrm{N}=94,72 \%$ of the sample $)$ and just over a quarter were women $(\mathrm{N}=36,28 \%$ of the sample). Participants' ages ranged from 18 to 66 years - the mean age of participants was 27.8 years $(\mathrm{SD}=8.1)$. The distribution of educational background was fairly equal, including those educated to high school level $(\mathrm{N}=38$, $29 \%$ of the sample), to diploma level $(\mathrm{N}=49,38 \%)$ and to university level $(\mathrm{N}=43$, $33 \%)$. The majority of participants were born in Tehran ( $\mathrm{N}=85,65.4 \%$ of the sample), with sizeable numbers from Shiraz $(\mathrm{N}=25,19.2 \%)$ and Esfahan $(\mathrm{N}=11,8.5 \%)$. Most participants defined their ethnicity as Persian $(\mathrm{N}=105,81 \%$ of the sample) and the remainder as Balochi $(\mathrm{N}=18,14 \%)$ or Azeri Turk $(\mathrm{N}=7,5 \%)$. There was a fairly even distribution of political orientation -60 participants defined themselves as "conservatives" ( $46 \%$ of the sample) and 70 as "reformists" $(54 \%){ }^{4}$

\section{Instruments}

\section{Iranian National Identity}

Iranian national identity was assessed using an adapted version of Cinnirella's (1997) British national identity scale, which is based on Social Identity Theory (Tajfel, 1982). The word "British" was substituted with the word "Iranian". The scale consists of items that measure correlated aspects of social identity, such as affect ("To what extent do you feel pleased to be Iranian?"), salience ("To what extent do you feel Iranian") and centrality ("How important to you is being Iranian?" Each item was scored on an 8-point Likert scale and a mean score of the seven items was calculated in order to produce a single overall Iranian national identity composite score. A higher score indicates a stronger national identity. Consistent with previous studies, the scale manifested a good internal reliability: $\alpha=.85$.

\section{Muslim Religious Identity}

Given our interest in Muslim religious identity as a social identity, in parallel with our conceptualization of Iranian national identity as a social identity, Cinnirella's (1997) scale was adapted to measure Muslim religious identity. The word "British" was substituted with the word "Muslim". In order to capture the institutional nature of religious identity, an extra item was added to the scale: "To what extent do you participate in activities and events associated with Muslims?" No distinction was made between Sunni and Shiite subgroup identities, since the vast majority of Iranians are Shiite and differences between Sunnis and Shiites were not expected. Each item was scored on an 8-point Likert scale and a mean score of the eight items was calculated in order to produce a single overall Muslim religious identity composite score. A higher score indicates a stronger religious identity. The scale manifested an excellent internal reliability: $\alpha=.95$.

\footnotetext{
"In the questionnaire, the Persian terms "osoolgaraa" and "eslahtalab" were used to refer to "conservative" and "reformist", respectively.
} 


\section{Antisemitism}

Participants' level of antisemitism was measured using an adapted version of Todosijevic and Enyedi's (2002) Antisemitism Scale (see appendix 1) The scale included items that tapped into participants' evaluation of Jews ${ }^{5}$ (e.g. 'It's better to have nothing to do with Jews") and their endorsement of long-standing anti-Jewish stereotypes (e.g. "There is a secret Jewish conspiracy"). Some items were re-worded in order to fit within the Iranian context and items deemed to be irrelevant to the Iranian context were removed. A new item that tapped into Holocaust denial, which is an important component of Iranian antisemitism (Jahanbegloo, 2007), was added to the scale: "The Holocaust is often exaggerated by Jews." Each item was scored on an 8-point Likert scale and a mean score of the items was calculated in order to produce a single overall antisemitism composite score. A higher score indicates a higher level of antisemitism. The internal reliability of the scale was excellent, $\alpha=.89$.

\section{Anti-Zionism}

Anti-Zionism was measured using an adapted version of the Attitudes Towards Israel Scale (Cohen et al., 2009) (see appendix 2). The scale assesses individuals' levels of pro-Israeli sentiment (e.g. I strongly support the Israeli cause) and of their endorsement of attacks against Israel ${ }^{6}$ (e.g. "Palestinian attacks on Israel are justified). Moreover, additional items were created and included in the scale in order to measure the level of perceived threat associated with Israel, such as: "Israel threatens Iran's competence and control in the world." This was deemed necessary given the history of problematic intergroup relations between Iran and Israel (Takeyh, 2006). As can be seen in the appendices, the antisemitism and anti-Zionism scales were sufficiently different so as to capture each form of prejudice. The two scales have been successfully employed in previous research. Each item was scored on an 8-point Likert scale and a mean score of the items was calculated in order to produce a single overall anti-Zionism composite score. A higher score indicates a higher level of antiZionism. The internal reliability of the scale was good, $\alpha=.8$.

\section{Political Trust}

Participants' level of political trust was measured using both the Trust in Politicians and the Trust in the Political System scales (Mutz \& Reeves, 2005). The Trust in Politicians scale includes items, such as "Politicians generally have good intentions," in order to measure the level of trust in politicians, and the Trust in the Political System scale includes items, such as "At present I feel very critical of our political system," in order to measure the level of trust people have in the political system. The items were slightly re-worded in order to be applicable to the Iranian context - for instance, the word "US" was substituted by the word "Iranian." Each item was scored on an 8-point Likert scale and a mean score of the items was calculated in order to produce a single overall political trust composite score. A higher score indicates a higher level of political trust. The internal reliability of the scale was excellent, $\alpha=$ 92 .

\footnotetext{
${ }^{5}$ The term "yahudian" (literally "Jews") was used to refer to Jews. While the singular noun "yahud" has negative connotations in Persian, the plural term "yahudian" does not. It is also much more commonly used than the alternative term "kalimi" (a more literary term for Jews).

${ }^{6}$ The Persian term "esrail" was used to refer to the State of Israel. In political rhetoric, the term "regime seihonisti" (literally "Zionist Regime") is often used but has negative, delegitimizing connotations.
} 


\section{Identity Threat Measure}

A new scale was developed to measure participants' level of identity threat, as defined in Identity Process Theory (see apprendix 3). The scale consisted of seven items, each of which tapped into participants' perceived level of each principle. The scale included items such as "I feel unique and distinctive" (distinctiveness) and "I feel that I have competence and control in my life" (self-efficacy). Each item was scored on an 8-point Likert scale and a mean score of the items was calculated in order to produce a single overall identity threat composite score. Theoretically, it is possible, and even likely, for individuals to perceive high levels of one principle but low levels of another and, thus, it was not anticipated that all of the items would be highly correlated. However, the overall score would provide a general sense of perceived identity threat among participants. The internal reliability of the scale was acceptable, $\alpha=.74$.

\section{RESULTS}

Table 1 below shows the mean scores on each of the main variables.

[Insert table 1 here]

\section{Correlations}

Although Iran is an Islamic theocracy and the country is officially defined as an Islamic Republic, there was in fact no significant correlation between Iranian national identity and Muslim religious identity, $r=-.04, p>0.05$, suggesting that it was possible to be highly identified with the nation without identifying with the Islamic religion. Both Iranian national identity and Muslim religious identity were strongly associated with political trust, $r=.42, p<.005$ and $r=.75, p<.005$ respectively, suggesting that these identities may be shaped by the messages and representations disseminated by the government. In partial support of hypothesis 4, Iranian national identity was correlated with anti-Zionism, $r=.58, p<.005$, but not with antisemitism, $r=.12, p>.05$. Conversely, Muslim religious identity was strongly associated with both antisemitism and anti-Zionism, $r=.77, p<.005$ and $r=.52, p<.005$ respectively, indicating that both anti-Zionism and antisemitism may be regarded as tenets of this identity. In partial support of hypothesis 4 , political trust was strongly associated with both antisemitism and anti-Zionism, $r=.84, p<.005$ and $.84, p<.005$ respectively. In support of hypothesis 1 , antisemitism and anti-Zionism were correlated, $r=.62$, $p<.005$, suggesting that the two forms of prejudice were associated in the minds of participants. Furthermore, in support of hypothesis 2, identity threat was strongly associated with antisemitism, $r=.83, p<.005$, and moderately associated with antiZionism, $r=.58, p<.005$, suggesting that individuals with a threatened sense of self may particularly susceptible to these forms of prejudice.

\section{Differences between gender, education and political orientation groups}

Male and female participants were compared on their levels of antisemitism and antiZionism, respectively. The mean score of anti-Zionism among male participants was $5.99(S D=1.31)$ and the mean score for female participants was $5.24(S D=1.2)$. The gender difference was found to be statistically non-significant using an independentsamples $t$-test, $t(128)=2.97, p>.005$, which supported hypothesis 2 . The mean score for antisemitism among male participants was $5.29(S D=1.46)$ and the mean score among female participants was $5.48(S D=1.35)$. In support of hypothesis 2 , the 
difference was found to be statistically non-significant using an independent samples $t$-test, $t(128)=0.41, p>0.05$, indicating that there was no statistically significant difference between the levels of antisemitism manifested by male and female participants, respectively.

Participants were compared in terms of their level of education. The mean score of anti-Zionism among participants educated to high school level was 5.71 ( $S D$ $=1.07)$, among those educated to diploma level it was $5.82(S D=1.47)$, and among those educated to university level it was $5.8(S D=1.37)$. A one-way ANOVA was used to test for differences in levels of anti-Zionism among the three groups, which revealed no significant differences between the three groups, $F(2,127)=0.82$, $p>0.05$. This provided partial support of hypothesis 2 . The mean score for antisemitism among participants educated to high school level was $5.58(S D=1.43)$, among those educated to diploma level it was $5.38(S D=1.46)$, and among those educated to university level it was 5.08 ( $\mathrm{SD}=1.36)$. A one-way ANOVA was used to test for differences in levels of antisemitism among the three groups, which revealed no significant differences between them, $F(2,127)=1.29, p>0.05$, providing support for hypothesis 2 . In short, there was no evidence that participants differed in their levels of antisemitism and anti-Zionism in accordance with their level of education.

Participants were also compared in terms of their political orientation. The mean score of anti-Zionism among those identified with political conservatives was $6.65(S E=.1)$ and that of those identified with the political reformists was 5.04 ( $S E=$ .15). Although both scores were high (above the mid-point of the Likert scale), the difference was found to be statistically significant using an independent-samples $t$ test, $t(128)=8.8, p<.001$, indicating that political conservatives manifested significant higher levels of anti-Zionism than political reformists. The mean score for antisemitism among political conservatives was $6.31(S E=.09)$ and that among political reformists was $4.52(S E=.16)$. The difference was found to be statistically significant using an independent-samples $t$-test, $t(128)=9.16, p<.001$, indicating that political conservatives manifested significant higher levels of antisemitism than political reformists. In short, although both conservatives and reformists manifest rather high levels of antisemitism and anti-Zionism, the conservatives tended to score more highly on these scales. This provides partial support for hypothesis 2 .

Given that there was an observable difference in scores of antisemitism and anti-Zionism among the two political orientation groups, antisemitism and antiZionism scores were compared within each group, that is, among the conservatives and reformists, respectively. On average, conservative participants manifested significantly greater anti-Zionism $(M=6.65, S E=.09)$ than antisemitism $(M=5.31$, $S E=.09, t(59)=2.3, p<.05)$, and the same difference was observable among reformists who also manifested greater anti-Zionism $(M=5.04, S E=.15)$ than antisemitism $(M=4.52, S E=.16, t(69)=3.54, p<.001)$. In all four cases, however, scores were above the mid-point on the Likert scale and, thus, high. However, conservatives perceived Jews as posing a greater threat to $\operatorname{Iran}(M=6.57, S E=.14)$ than the State of Israel $(M=5.95, S E=.27, \mathrm{t}(59)=-2.05, p<.05)$, and the same difference was observable among reformists who also perceived Jews as posing a greater threat to Iran $(M=4.39, S E=.28)$ than the State of Israel $(M=3.5, S E=.26$, $t(69)=2.80, \mathrm{p}<.01)$. Interestingly, among the reformists, the perceived threat of Israel was below the mid-point of the Likert scale and, thus, low. 


\section{Interactions between social identities and political trust}

A median split was performed on the independent variables of Iranian national identification and political trust, respectively, in order to split the sample into "high" versus "low." A two-way ANOVA indicated significant main effects of level of Iranian national identification $(F(1,126)=90.84, p<0.001)$ and level of political trust $(F(1,126)=52.17, p<0.001)$ on anti-Zionism. In addition, a significant level of Iranian national identification $\mathrm{X}$ level of political trust interaction was found $(F(1$, $126)=41.30, \mathrm{p}<0.001)$. As indicated in figure 1 and in support of hypothesis 4 , this interaction demonstrates that political trust does appear to have an effect for low identifiers with the Iranian national ingroup. Low national identifiers with high political trust appear to score significantly higher on anti-Zionism than low national identifiers with low political trust.

\section{[Insert figure 1 here]}

Similarly, a median split was performed on the independent variables of Muslim religious identification and political trust, respectively, in order to split the sample into "high" versus "low." Another two-way ANOVA was conducted to ascertain any potential interaction of level of Muslim religious identification and level of political trust. There was a significant main effect of level of Muslim religious identification $(F(1,126)=27.58, p<0.001)$ and no significant effect of level of political trust $(F(1$, $126)=2.21, p>0.05)$ on level of antisemitism. However, a significant level of Muslim religious identification $X$ level of political trust interaction was found $(F(1$, $126)=4.67, \mathrm{p}<0.05)$. As indicated in figure 2 and in partial support of hypothesis 4 , this interaction demonstrates that political trust does appear to have an effect for low identifiers with the Islamic religion. Low religious identifiers with high political trust appear to score significantly higher on antisemitism than low religious identifiers with low political trust.

\section{[Insert figure 2 here]}

\section{Multiple regression analyses \\ Predictors of antisemitism}

In order to gain more in-depth insight into the relationships between the predictor variables and antisemitism, a series of 4 regression models were constructed and examined. Model 1 included the political orientation variable only. Model 2 included political orientation and level of political trust. Model 3 included political orientation; political trust and Muslim identification. Model 4 included political orientation; political trust; Muslim identification; and identity threat as predictor variables.

\section{[Insert table 2 about here]}

Model 1, which included political orientation only, explained a statistically significant proportion of the variance in the antisemitism measure among respondents $\left(\mathrm{R}^{2}=.39\right.$, $F(1,129)=83.46, p<.001)$. Model 2, which incrementally included level of political trust, yielded a substantial increase in the explanatory power $\left(\mathrm{R}^{2}=.71, F(2,129)=\right.$ $151.89, p<.001)$, accounting for almost a quarter of the variance in the antisemitism score. In this model, political orientation was no longer a statistically significant predictor, but political trust was strongly associated with antisemitism. In model 3, which included Muslim identification alongside the aforementioned variables, the $\mathrm{R}^{2}$ 
was raised to $.75\left(\mathrm{DR}^{2}=0.04, F(2,129)=128.56, p<.001\right)$, accounting for just over three-quarters of the variance in the antisemitism score. Both political trust and Muslim identification remained strongly associated with antisemitism. In model 4, which included identity threat alongside the aforementioned variables, the $\mathrm{R}^{2}$ was raised to $.76\left(\mathrm{DR}^{2}=0.01, F(5,129)=81.98, p<.001\right)$. All of the variables, apart from political orientation, remained statistically significant predictors of antisemitism. Identity threat was also significantly associated with antisemitism.

\section{Predictors of anti-Zionism}

In order to gain more in-depth insight into the relationships between the predictor variables and anti-Zionism, a further set of multiple regression models were constructed and examined. Model 1 included the political orientation variable only. Model 2 included political orientation and level of political trust. Model 3 included political orientation; political trust and Iranian national identification. Model 4 included political orientation; political trust; Muslim identification; and identity threat.

[Insert table 3 about here]

Model 1, which included political orientation only, explained a statistically significant proportion of the variance in the anti-Zionism measure among respondents $\left(\mathrm{R}^{2}=.38\right.$, $F(1,129)=77.42, p<.001)$. Model 2, which incrementally included level of political trust, yielded a substantial increase in the explanatory power $\left(\mathrm{R}^{2}=.71, F(2,129)=\right.$ $157.27, p<.001)$, accounting for almost a quarter of the variance in the anti-Zionism score. In this model, political orientation was no longer a statistically significant predictor, but political trust was strongly associated with anti-Zionism. In model 3, which included Iranian national identification alongside the aforementioned variables, the $\mathrm{R}^{2}$ was raised to $.77\left(\mathrm{DR}^{2}=.06, F(3,129)=143.56, p<.001\right)$, accounting for over three-quarters of the variance in the anti-Zionism score. Both political trust and Iranian national identification remained strongly associated with anti-Zionism. In model 4, which included identity threat alongside the aforementioned variables, the $\mathrm{R}^{2}$ was raised to $.79\left(\mathrm{DR}^{2}=.02, F(4,129)=116.04, p<.001\right)$. All of the variables, apart from political orientation, remained statistically significant predictors of antiZionism. Identity threat was also significantly associated with anti-Zionism.

\section{DISCUSSION}

The results of this exploratory study provide preliminary insight into the correlates of antisemitism and anti-Zionism in Iran and, thus, complement the qualitative studies that have preceded it (e.g. Jaspal, 2013a, 2014). It is noteworthy that, despite the use of two distinct scales to tap into antisemitism and anti-Zionism, respectively, these forms of prejudice are correlated, which suggests that they are entwined and inseparable in the minds of some individuals. Indeed, it has been observed that in Iran there is much slippage between the categories "Israeli" and "Jew" which renders them difficult to delineate. This possibly reflects a bi-dimensional relationship between antisemitism and anti-Zionism (Cohen et al., 2009; Frindte et al., 2005). Furthermore, the multiple regression models for antisemitism and anti-Zionism suggested that the same social psychological mechanisms (with the same order of importance) underlie the two forms of prejudice. Israel and Jews seem to be viewed in a similar light - 
qualitative research among Iranians suggests that Jews are often held responsible for the actions of the State of Israel (Jaspal, 2014).

Although both reformist and conservative participants manifested significantly higher levels of anti-Zionism than antisemitism, which is consistent with the Iranian government's aim to construct Israel as Iran's "Significant Other" in the region (Triandafyllidou, 2002), individuals of both political orientations perceived Jews as posing a greater threat than the State of Israel. This clear example of antisemitism may constitute a by-product of Iran's anti-Zionist policy. More specifically, this may be attributed to the notion that Jews are viewed as a threatening "enemy within" (Bartov, 1998). In qualitative research, Iranians have indicated that they perceive Iranian Jews as disloyal to the Iranian national ingroup because of a supposed underlying loyalty to the State of Israel - they are often perceived as functioning as "agents" of Israel (Shahvar, 2009). Thus, despite the adamant assertions of the Iranian political establishment that the Islamic Republic is anti-Zionist and not antisemitic, these data suggest that, for our sample at least, the two forms of prejudice are less delineable (see also Cohen et al., 2009).

In support of hypothesis 2 , there were no significant differences in antisemitism or anti-Zionism among participants in accordance with level of education or gender. Although much research into antisemitism has indeed found such differences in the US and Europe (e.g. D'Alessio \& Stolzenberg, 1991; Quinley \& Glock, 1979; Selznick \& Steinberg, 1969), it appears that social representations of Israel and Jews are more coercive and hegemonic in the Iranian context and, thus, more pervasive across distinct social groups. Iranians are socialized in a context in which anti-Zionism is normative and antisemitism is at least passively endorsed (Jaspal, 2014). As highlighted in the results, there is a strong perception of threat to Iranian national identity from Israel and, in some cases, to Muslim religious identity from Jews. However, as predicted, political conservatives did manifest significantly higher levels of antisemitism and anti-Zionism than political reformists. This may be attributed to the constructed centrality of anti-Zionism to the conservative political agenda and the general desire among conservatives to remain faithful to the original tenets of the Iranian revolutionary ideology (Jaspal, 2013a). After the election of former conservative president Mahmoud Ahmadinejad, there was a reversal of some of the more liberal policies introduced by his reformist predecessor Mohammad Khatami. One such policy was a more pragmatic approach to the State of Israel. Although during the presidency of the reformist Mohammad Khatami Iran became a refuge for Holocaust deniers such as Wolfgang Fröhlich, Holocaust denial has become particularly associated with political conservatism in Iran. This became particularly important during Ahmadinejad's presidency during which he hosted the International Conference to Review the Global Vision of the Holocaust in 2006 (Jahanbegloo, 2007). Thus, both antisemitism and anti-Zionism have been more strongly associated with the conservative camp. However, even among reformists both forms of prejudice were still quite strongly manifested, which may be attributed to the prowess of these representations in Iran and their apparent acceptance at various levels of Iranian society.

Anti-Zionism is constructed as an important tenet of Iranian national identity, which is consistent with the revolutionary ideology that underpins contemporary Iranian nationhood (Takeyh, 2009). In support of hypothesis 4, there were significant main effects of Iranian national identity and political trust on anti-Zionism, as well as a significant interaction effect. More specifically, for low national identifiers, political trust had an important impact on anti-Zionism in that those who trusted the political 
system were significantly more anti-Zionist. Because Israel is constructed as a threat to the Iranian national ingroup, it is unsurprising that those highly identified with the nation should respond defensively (Brown, 2000). However, for low national identifiers, it seems that trust in the political system, which may be for reasons other than nationhood (e.g. the centrality of religion), is associated with anti-Zionism.

Moreover, the Iranian political establishment has consistently focused on demonizing the State of Israel and, thus, predictably, those who trust this political system are more likely to assimilate and accommodate its political messages, such as anti-Zionism. Similarly, various analysts have observed that, in some contexts, social representations of Muslim religious identity may indicate that it is legitimate and, in some cases, necessary to hate Jews (Baum \& Nakazawa, 2007; Kressel, 2009). In further support of hypothesis 4, there were significant main effects of Muslim religious identity and political trust on antisemitism, as well as a significant interaction effect. This mirrored the aforementioned interaction effect of Iranian national identity and political trust on anti-Zionism. Partly as a result of the IsraeliPalestinian conflict, which is often Islamicized as a conflict between Jews and Muslims (Litvak, 1998), and growing intergroup tensions in an atmosphere of global Islamophobia (Cinnirella, 2014), many Muslims may construe "Significant Others", such as the Jewish outgroup, as posing a threat to the religious ingroup. Indeed, as outlined above, there was a stronger perception of threat from Jews than from the State of Israel. Thus, those who were highly identified with the Muslim religious ingroup manifested greater antisemitism.

In accordance with Social Identity Theory (Brown, 2000; Tajfel, 1982) and Social Representations Theory (Moscovici, 1988) from social psychology, it is argued that those messages, ideas, myths and representations associated with salient group memberships will in turn acquire social and psychological salience (Breakwell, 2001). Accordingly, Iranians who valued their national and religious identities accepted and manifested the positions that they saw as being associated with these identities namely anti-Zionism and antisemitism, respectively. However, social identity appears to provide only a partial explanation of these forms of prejudice. The multiple regression models indicated that Iranian national and Muslim religious identities were significant but the weakest predictors of anti-Zionism and antisemitism, respectively.

There is evidence that the Iranian government has made, and continues to make, remarks that can legitimately be construed as antisemitic. Thus, it is unsurprising that individuals who trust the political system seem to assimilate and accommodate antisemitic messages associated with this political system. Similarly, the multiple regression models indicated that political trust was by far the strongest predictor of both forms of prejudice, although it made a stronger contribution to explaining anti-Zionism. This is understandable in view of the politicization of antiZionism (Takeyh, 2006) and the government's consistent dissemination of antiZionist messages to Iranians, most of whom have no first-hand contact with Israel or Zionism. It is similarly understandable that political trust predicts antisemitism because the political system has rendered religion and religious intergroup relations salient by accentuating the distinctive Shiite religious character of Iran and its longstanding enmity with Jews (Shahvar, 2009; Tsadik, 2010). In Iran, the government attempts to extend its influence to all spheres of social and religious life and its insistence on anti-Zionism, and to some degree antisemitism, has clearly had important repercussions for how people view Israel and Jews. However, it is noteworthy that the rhetoric of Israeli leaders and politicians that emphasizes the "Iranian threat" and that sometimes advocates pre-emptive military action against Iran 
is also likely to feed into the perceived enmity of Israel and, in many cases, of the Jewish people (see Jaspal \& Coyle, 2014; Klein, 2009).

After political trust, the strongest predictor of both antisemitism and antiZionism was the perception of identity threat. This provided support for hypothesis 5 . It may be the case that individuals who generally perceive insufficient levels of continuity, self-esteem, self-efficacy and distinctiveness will attempt to cope with threat by manifesting prejudice against their "Significant Others" - there is little doubt that Israel and Jews are constructed as Iran's Significant Others (Jaspal, 2013a; Shahvar, 2009). This follows a similar logic to Terror Management Theory, which suggests that individuals cope with death anxiety (or with threats to their continuity) by protecting their worldview. One important means of protecting one's worldview is by derogating outgroups who hold a distinct and contradictory worldview. This has been discussed in relation to both antisemitism and anti-Zionism (Cohen et al., 2009). Similarly, it may be that individuals whose identities are threatened (for whatever reason) may attempt to restore appropriate levels of their identity principles by manifesting prejudice towards outgroups. By engaging in antisemitic and anti-Zionist prejudice, individuals may enhance self-esteem through downward comparison (Wills, 1981), continuity by maintaining the worldview perceived to be associated with relevant social identities, distinctiveness from a "Significant Other" and selfefficacy by construing the outgroup as powerless. This finding is consistent with recent theorising in the field of Identity Process Theory (Cinnirella, 2014; Jaspal \& Cinnirella, 2010), but it would certainly benefit from further research using alternative methods.

\section{Limitations}

This study presents several limitations, which ought to be addressed in future research. First, the study relies on a small opportunity sample of 130 Iranians largely in the Iranian capital city Tehran, rather than a representative sample. It would be useful to conduct similar studies outside of the capital city, where anti-Zionism and antisemitism may be less politicized. This may also elucidate potential ethnic differences in attitudes towards Jews and Israel given that Iran is an ethnically diverse country. Ideally, one could broaden the recruitment strategy by engaging in convenience sampling in more of the districts in Tehran. This was partially attempted in the present study through recruitment in three socio-economically distinct districts in the city, but this could of course be bolstered with more districts and a larger sample. While a representative sample would be desirable, this is difficult in Iran where social research of this kind may be regarded with suspicion. Conducting research of this kind in Iran makes the researcher susceptible to harsh social and legal repercussions, which must be taken into consideration. Given the fact that the data come from a convenience sample, it is important to exercise caution interpreting the analysis presented - these statistical patterns are reported in relation to the sample, not the population. However, it is interesting that the statistical patterns observed are clearly echoed in some of the qualitative research into antisemitism and anti-Zionism among Iranians (Jaspal, 2014). Moreover, it is noteworthy that $56 \%$ of the sample was recruited online, which may constitute one means of gaining access to a more representative sample of Iranians, although this will naturally be limited to those with access to the Internet. In short, the results of this study must be considered with this limitation in mind - the results are suggestive but by no means conclusive.

Second, the correlational design of the study makes it impossible to make unequivocal statements about causality. This study elucidates the correlates of 
antisemitism and anti-Zionism and it is hoped the future research will tap into the causal mechanisms of these forms of prejudice through the use of experimental methods, possibly in an online setting in order to curb the limitations of face-to-face participant recruitment in Iran. It would, for instance, be useful to gauge the potential importance of social identification in antisemitism and anti-Zionism by manipulating the salience of relevant group memberships as well as the representations associated with them. This would complement existing research in the Social Representations Theory tradition (Breakwell, 2001) and bolster the theoretical implications of this study (Jaspal \& Breakwell, 2014). Moreover, while this cross-sectional study was intended to provide a snapshot of antisemitism and anti-Zionism at one particular point in time, future research ought to replicate the study by generating longitudinal data that can track changes in perceptions of Jews and Israel at distinct points in time. This would also provide insight into future convergences or divergences between antisemitism and anti-Zionism.

Third, it would be useful to gauge attitudes towards other ethnic and religious outgroups, such as the Bahai people, who are also subject to discrimination in Iran (Sanasarian, 2000). This would provide insight into the "position" of Jews vis-à-vis other ethnic and religious outgroups. It is important to emphasize that Jews and Israelis are not the only outgroups at the receiving end of discrimination in the Iranian context, but these outgroups are deemed to be important ones to examine due to (i) the political climate surrounding Israeli-Iranian relations and (ii) the fact that there is a large Jewish minority still resident in Iran. Moreover, antisemitism and anti-Zionism could further exacerbate already problematic intergroup and international relations, feeding into the Israeli "siege mentality" that has been discussed by intergroup relations scholars (Bar-Tal, 2000). In future research, the impact of the Israeli "siege mentality", which has been described in relation to the rhetoric of Israeli leaders (BarTal, 2000), on Iranian attitudes towards Jews and Israel - more specifically, does the perceived threat of an Israeli attack on Iran fan the flames of Iranian anti-Zionism and antisemitism?

Despite these limitations, the present study does provide some preliminary quantitative insight into antisemitism and anti-Zionism in Iran. These results may lack external validity, given that the sample is not representative, but the inclusion of distinct political orientations and other demographic groups in the sample provides scope for suggestive, though not conclusive, remarks about how antisemitism and anti-Zionism may function in the Iranian general population. In a country with a Jewish population of approximately 25,000-30,000 according to recent estimates (Sarshar, 2014; Yeroushalmi, 2013), the study of antisemitism and anti-Zionism is of critical importance. Iranian leaders habitually delegitimize the State of Israel and deny the Holocaust, yet claim that they are "only" anti-Zionist - the present study exposes the fallacy of this claim in even a small convenience sample.

Although exploratory and preliminary in scope, this study demonstrates that attitudes towards Jews and Israel appear to be troublingly negative, even among the most educated sections of Iranian society and among the political "reformists" who are often thought to be in favor of social and political reform, and that trust in the Iranian political system and the content and strength of their national and religious identities seem to be closely associated with these forms of prejudice. The results also suggest a potential link between threatened identity and outgroup prejudice. Social and political discourses continue to threaten identity among the Iranian people, to construct antisemitism and anti-Zionism as central tenets of national and religious identities and, accordingly, to construct Israel and the Jewish people as legitimate 
targets for delegitimization and demonization, providing a convenient outgroup for protecting one's own identity from threat. It is hoped that this article will draw further attention to the inter-related problems of antisemitism and anti-Zionism, in order to understand the social psychological mechanisms of these forms of prejudice in the Islamic Republic of Iran and indeed elsewhere.

\section{REFERENCES}

Adorno, T. W., Frenkel-Brunswik, E., Levinson, D. J., \& Sanford, R. N. (1950). The authoritarian personality. New York: Harper and Row.

Asayesh, H., Ab Halim, A., Jawan, J.A. \& Shojaei, N.S. (2010). Political Party in Islamic Republic of Iran: A Review. Journal of Politics and Law, 4(1), 221-30.

Bartov, O. (1998). Defining enemies, making victims: Germans, Jews, and the Holocaust' American Historical Review, 103(3), 771-816.

Baum, S.K. (2009). Christian and Muslim Anti-Semitic Beliefs. Journal of Contemporary Religion, 24(2), 137-156

Baum, S.K. \& Nakazawa, M. (2007). Anti-Semitism versus Anti-Israeli Sentiment. Journal of Religion \& Society, 9, 1-8.

Beller, S. (2007). Antisemitism: A very short introduction. Oxford: Oxford University Press.

Breakwell, G.M. (1986). Coping with threatened identities. London: Methuen.

Breakwell, G.M. (2001). Social representational constraints upon identity processes. In K. Deaux \& G. Philogène (eds.), Representations of the social: bridging theoretical traditions (pp. 271-284). Oxford: Blackwell.

Brown, R. (2000). Social identity theory: past achievements, current problems and future challenges. European Journal of Social Psychology, 30, 745-778.

Chesler, P. (2003). The new anti-Semitism: the current crisis and what we must do about it. San Francisco, CA: Jossey-Bass.

Cinnirella, M. (2014). The role of perceived threat and identity in Islamophobic prejudice. In R. Jaspal \& G.M. Breakwell (eds), Identity process theory: identity, social action and social change (pp.253-269). Cambridge: Cambridge University Press.

Cinnirella, M. (1997b). Towards a European identity? Interactions between the national and European social identities manifested by university students in Britain and Italy. British Journal of Social Psychology, 36, 19-31.

Cohen, F., Jussim, L., Harber, K.D. \& Bhasin, G. (2009). Modern Anti-Semitism and Anti-Israeli Attitudes. Journal of Personality and Social Psychology, 97(2), 290-306. 
Dabashi, H. (2011). The Green Movement in Iran. Piscataway, NJ: Transaction Publishers.

D'Alessio, S.J. \& Stolzenberg, L. (1991). Anti-Semitism in America: The Dynamics of Prejudice. Sociological Inquiry, 61, 359-66.

Dunbar, E. \& Simonova, L. (2003) Individual difference and social status predictors of anti-Semitism and racism US and Czech findings with the prejudice/tolerance and right wing authoritarianism scales. International Journal of Intercultural Relations, $27,507-523$

Fein, H. (1987). Dimensions of antisemitism: attitudes, collective accusations and actions. In H. Fein (ed.), The Persisting Question: Sociological Perspectives and Social Contexts of Modern Antisemitism, Current research on Antisemitism (pp.6785). Berlin/New York.

Fischel, J.R. (2005). The New Anti-Semitism. Virginia Quarterly Review, 81(3), 22534.

Frindte, W., Wettig, S. \& Wammetsberger, D. (2005). Old and new anti-Semitic attitudes in the context of authoritarianism and social dominance orientation: Two studies in Germany. Peace and Conflict: Journal of Peace Psychology, 11(3), 239-66.

Gregory, W.E. (2001). Scapegoating. In E. Craighead \& C.B. Nemeroff (eds), The Corsini Encyclopedia of Psychology and Behavioral Science (3rd edn, Vol. 4). New York: Wiley.

Herf, J. (2006). The Jewish enemy: Nazi propaganda during World War II and the Holocaust. Cambridge, MA: Harvard University Press.

Jahanbegloo, R. (2007). Holocaust Denial in Iran and Anti-Semitic Discourse in the Muslim World. Paper presented at the Centre for Minority Studies, History Department, Royal Holloway University of London, Egham, 2007.

Jaspal, R. (2013a). Anti-Semitism and Anti-Zionism in Iran. Israel Affairs, 19(2), 231-58.

Jaspal, R. (2013b). Social representations of Jews and the Jewish State among Iranian adolescents: A qualitative study. In R. Jaspal (Chair), Continuities and Discontinuities of Anti-Jewish Sentiment in Societal Discourse. Symposium conducted at the $29^{\text {th }}$ Annual Meeting of the Association of Israel Studies, Los Angeles, CA, 24-26 June 2013.

Jaspal, R. (2014). Antisemitism and Anti-Zionism: Representation, Cognition and Everyday Talk. Farnham: Ashgate.

Jaspal, R. \& Breakwell, G.M. (eds.) (2014). Identity Process Theory: Identity, Social Action and Social Change. Cambridge: Cambridge University Press. 
Jaspal, R. and Coyle, A. (2014). Threat, Victimhood and Peace: Debating the 2011 Palestinian UN State Membership Bid. Digest of Middle East Studies, 23(1), 190-214.

Jaspal, R. \& Cinnirella, M. (2010). Media representations of British Muslims and hybridised threats to identity. Contemporary Islam:

Dynamics of Muslim Life, 4(3), 289-310.

Kaplan, E.H. \& Small, C.A. (2006). Anti-Israel Sentiment Predicts Anti-Semitism in Europe. Journal of Conflict Resolution, 50(4), 548-561.

Klein, A. (2009). Characterizing "the Enemy": Zionism and Islamism in the Iranian and Israeli Press. Communication, Culture \& Critique, 2, 387-406.

Klier, J.D. \& Lambroza, S. (eds.) (1992). Pogroms: Anti-Jewish Violence in Modern Russian History. Cambridge: Cambridge University Press.

Konig, R., Scheepers, P. \& Falling, A. (2001). Research on antisemitism: A review of previous findings and the case of the Netherlands in the 1990s. In K. Phalet \& A. Örkény (eds), Ethnic minorities and inter-ethnic relations in context: A Dutch Hungarian comparison. Aldershot: Ashgate.

Kressel, N. (2012). "The sons of pigs and apes": Muslim antisemitism and the conspiracy of silence. Dulles, VA: Potomac Books.

Küntzel, M. (2010). Iranian anti-Semitism: stepchild of German National Socialism. Israel Journal of Foreign Affairs, 4(1) 43-51.

Levy, H. (1999). Comprehensive History of the Jews of Iran. Costa Mesa: Mazda Publishers.

Litvak, M. (1998). The Islamicization of the Israeli-Arab conflict: the case of Hamas. Middle Eastern Studies, 23(1), 148-63.

Litvak, M. (2006). The Islamic Republic of Iran and the Holocaust: Anti-Semitism and Anti-Zionism. Journal of Israeli History, 25(1), 267-84

Milgram, S. (1963). Behavioral study of obedience. Journal of Abnormal and Social Psychology, 67, 371-378.

Miller, A.H. \& Listhaug, O. (1990). Political Parties and Confidence in Government: A Comparison of Norway, Sweden and the United States. British Journal of Political Science, 29, 357-86.

Moscovici, S. (1988). Notes towards a description of social representations. European Journal of Social Psychology, 18, 211-250.

Mutz, D.C. \& Reeves, B. (2005). The New Videomalaise: Effects of Televised Incivility on Political Trust. American Political Science Review, 99(1), 1-15. 
Palmer-Harik, J. (2004). Hezbollah: The Changing Face of Terrorism. London, I.B. Tauris \& Co Ltd

Quinley, H.E. \& Glock, C.Y. (1979). Anti-Semitism in America. New York: Free Press.

Raab, E. (1983). Anti-Semitism in the 1980s. Midstream, 29,11-18.

Sanasarian, E. (2000). Religious minorities in Iran. Cambridge: Cambridge University Press

Sarshar, H. (2014). Days of Darkness, Days of Light: The Unknown Story of Iran's Jews. Reform Judaism. http://reformjudaismmag.org/PrintItem/index.cfm?id=1013\&type=Articles (retrieved 1 February 2014)

Selznick, G.J. \& Steinberg, S. (1969). The Tenacity of Prejudice: Anti-Semitism in Contemporary America. New York: Harper and Row.

Shahvar, S. (2009). The Islamic Regime in Iran and Its Attitude towards the Jews: The Religious and Political Dimensions. Immigrants \& Minorities, 27(1), 82-117.

Smith, T.W. (1991). What Do Americans Think About Jews? Working Papers on Contemporary Anti-Semitism. New York: American Jewish Committee.

Tajfel, H. (1982). Social psychology of intergroup relations. Annual Review of Psychology, 33, 1-39.

Takeyh, R. (2006) Iran, Israel and the Politics of Terrorism. Survival, 48(4), 83-96.

Todosijević, B. \& Enyedi, Zs. (2002). Anti-Jewish prejudice in contemporary Hungary: a socio-psychological causal model. Social Thought and Research, 24(1-2), 313-42.

Triandafyllidou, A. (2002) Negotiating Nationhood in a Changing Europe. Views from the Press. Lewiston, NY: The Edwin Mellen Press.

Tsadik, D. (2005). Religious disputations of Imami Shi-is against Judaism in the late eighteenth and nineteenth centuries. Studia Iranica, 34, 95-143.

Tsadik, D. (2010). Jews in the pre-constitutional years: the Shiraz Incident of 1905. Iranian Studies, 43(2), 239-63.

Turner, J. C., Hogg, M. A., Oakes, P. J., Reicher, S. D. \& Wetherell, M. S. (1987). Rediscovering the social group: a self-categorization theory. Oxford: Blackwell.

Weil, F.D. (1985) The Variable Effects of Education on Liberal Attitudes: A Comparative- Historical Analysis of Anti-Semitism Using Public Opinion Survey Data. American Sociological Review, 50(4), 458-474. 
Wills, T.A. (1981). Downward comparison principles in social psychology. Psychological Bulletin, 90(2), 245-271.

Yeroushalmi, D. (ed.) (2013). Light and Shadows: The Story of Iranian Jews. Seattle, WA: University of Washington Press.

\section{TABLES \& FIGURES}

Table 1: Mean scores on the main variables

\begin{tabular}{|l|r|r|}
\hline & Mean & $\begin{array}{l}\text { Standard } \\
\text { deviation }\end{array}$ \\
\hline $\begin{array}{l}\text { Iranian national } \\
\text { identity }\end{array}$ & 4.52 & 1.27 \\
\hline $\begin{array}{l}\text { Muslim religious } \\
\text { identity }\end{array}$ & 5.15 & 1.9 \\
\hline Political trust & 4.71 & 1.56 \\
\hline Antisemitism & 5.34 & 1.43 \\
\hline Anti-Zionism & 5.78 & 1.32 \\
\hline Identity threat & 4.47 & 1.19 \\
\hline N=130
\end{tabular}

Figure 1: Two-way ANOVA interaction effects between Iranian national identification and political trust on anti-Zionism

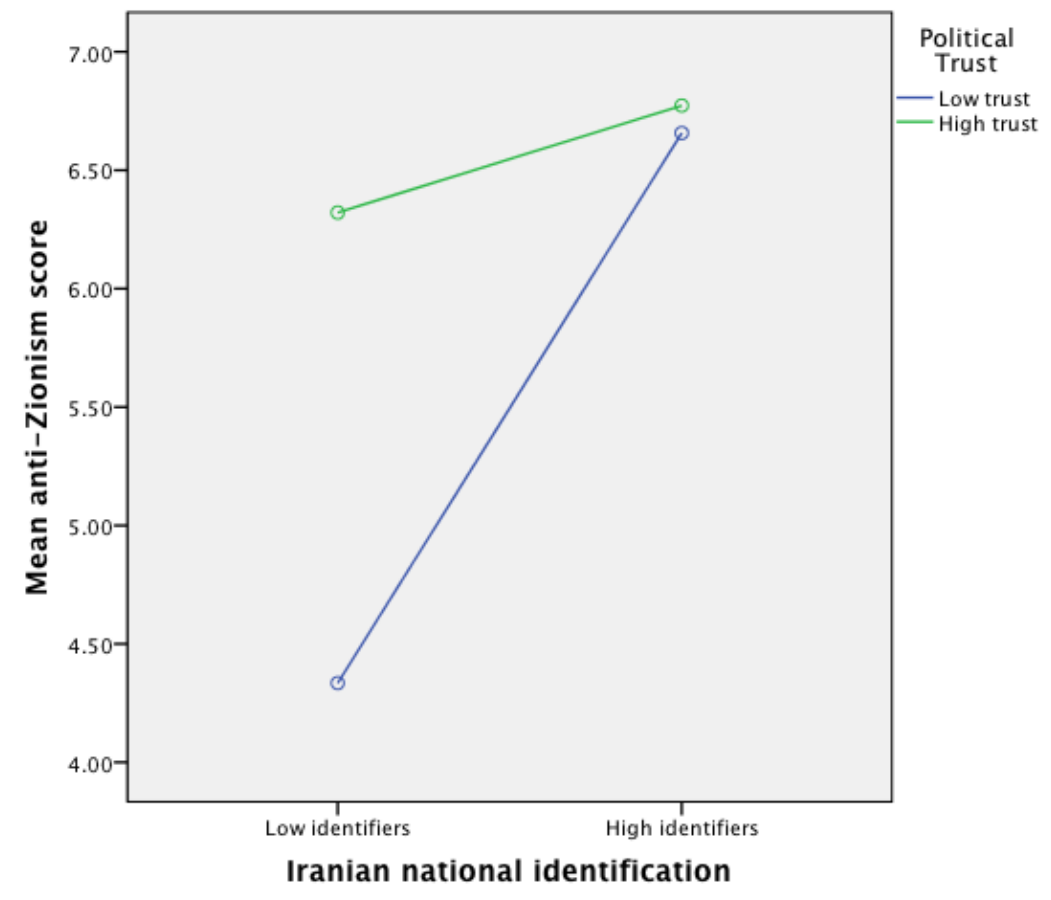

Figure 2: Two-way ANOVA interaction effects between Muslim religious identification and political trust on antisemitism 


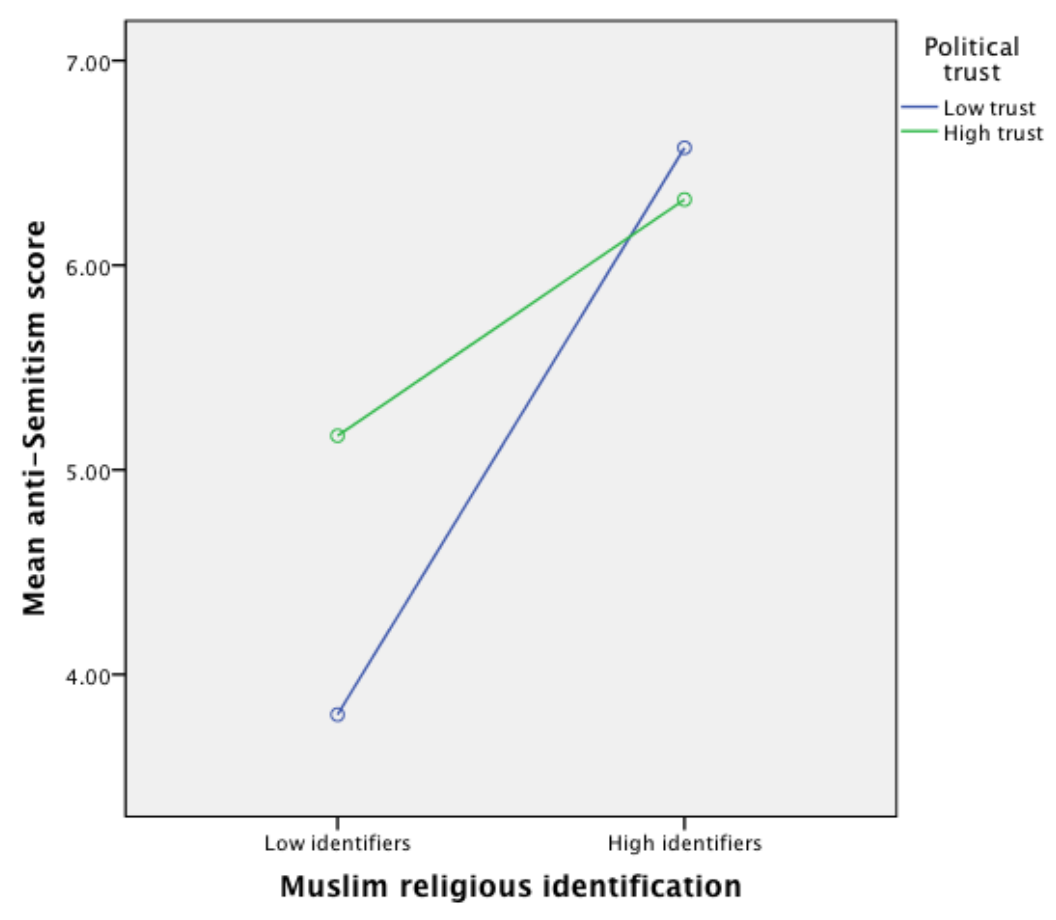

Table 1: Predictors of anti-Zionism.

Standardized Regression Weights and $\mathrm{R}^{2}$ Values for Regression

\begin{tabular}{|c|c|c|c|c|}
\hline PREDICTORS & Model 1 & Model 2 & Model 3 & Model 4 \\
\hline $\begin{array}{l}\text { Political } \\
\text { orientation }\end{array}$ & $.61 *$ & .02 & .03 & .07 \\
\hline Political trust & - & $.83 *$ & $.71 *$ & $.92 *$ \\
\hline $\begin{array}{l}\text { Iranian } \\
\text { identification }\end{array}$ & - & - & $.27 *$ & $.20 *$ \\
\hline Identity threat & - & - & - & $.25 *$ \\
\hline MODEL R ${ }^{2}$ & .38 & .71 & .77 & .79 \\
\hline
\end{tabular}

Note: Entries in bold with an asterisk are statistically significant $(\mathrm{p}<.05)$. Cells without entries indicate that this predictor was not used in the model.

Table 2: Predictors of antisemitism.

Standardized Regression Weights and $\mathrm{R}^{2}$ Values for Regression

\begin{tabular}{|c|c|c|c|c|}
\hline PREDICTORS & Model 1 & Model 2 & Model 3 & Model 4 \\
\hline $\begin{array}{l}\text { Political } \\
\text { orientation }\end{array}$ & $.63 *$ & .05 & -.09 & -.08 \\
\hline Political trust & - & $.80 *$ & $.63 *$ & $.51 *$ \\
\hline $\begin{array}{l}\text { Muslim } \\
\text { identification }\end{array}$ & - & - & $.37 *$ & $.22 *$ \\
\hline Identity threat & - & - & - & $.27 *$ \\
\hline MODEL $\mathbf{R}^{2}$ & .39 & .71 & .75 & .76 \\
\hline
\end{tabular}

Note: Entries in bold with an asterisk are statistically significant $(\mathrm{p}<.05)$. Cells without entries indicate that this predictor was not used in the model. 


\section{APPENDICES}

\section{Appendix 1}

Antisemitism Scale

Please indicate the extent (from $1=$ not at all to $8=$ extremely) to which you agree with each of these statements

1. Marriage between Jews and Muslims does not do good to either.

2. There is a secret Jewish conspiracy.

3. The Holocaust is often exaggerated by Jews.

4. Jews are often accused of ridiculous things.

5. It is better to have nothing to do with Jews.

6. Iranian Jews suffered as much as others in Iran.

7. Jews threaten the survival of Muslims.

8. Muslims are better than Jews.

9. Jews threaten the competence and control of Muslims in the world.

10. It makes sense for Muslims to dislike Jews.

\section{Appendix 2}

Anti-Zionism Scale

Please indicate the extent (from $1=$ not at all to $8=$ extremely) to which you agree with each of these statements

1. The Arabs have been terrorized by Israel for decades.

2. The Jews do not deserve a homeland in Israel.

3. The Israelis have the right to fight against Palestinian terrorism using any means necessary.

4. Israeli incursions into the West Bank and Gaza are necessary to preserve Israeli security.

5. Palestinian attacks on Israel are justified.

6. Israel has attempted to forcibly expel the Palestinians for years.

7. Many Israelis, or their ancestors, were forcibly expelled from Arab countries in 1948.

8. Israel threatens the survival of Iran.

9. Iran is better than Israel.

10. Israel threatens Iran's competence and control in the world.

11. It makes sense for Iranians to dislike Israel.

\section{Appendix 3}

Identity Threat Scale

Please indicate the extent (from $1=$ not at all to $8=$ extremely) to which each of these statements is true of you in general.

1. I feel that my past, present and future are connected.

2. My life seems meaningful.

3. I feel that I have competence and control over my life.

4. I am accepted and included by people who matter to me.

5. I feel unique and distinctive.

6. I feel good about myself.

7. I feel that my sense of self is coherent. 